\title{
POOLED DATABASE OF OZYORSK POPULATION EXPOSED TO COMPUTED TOMOGRAPHY
}

\author{
Fomin E.P.1, Osipov M.V.2
}

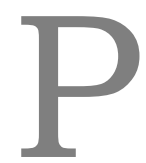

urpose. Creation of pooled database of persons underwent computed tomography (CT) for assessing the risk of possible long-term consequences of diagnostic exposure to a low doses of ionizing radiation.

Material and methods. Archive protocols of computed tomography of Ozyorsk residents collected since the time of first using the $\mathrm{CT}$ in medical departments of Chelyabinsk region has been digitized, verified and integrated into an electronic database. Retrospective follow-up study provides the information on 22,705 CT examinations of Ozyorsk residents who underwent computed tomography during the period from 1993 to 2017.

Results. The total number of examined patients was 14894 , while $70.1 \%$ of patients were single-time examined during the follow-up period. The maximum number of second examinations of one patient was 19 . The most of CT protocols collected $(61.5 \%)$ was represented by examinations of the head. The average effective dose for each examination was 3.2 $\mathrm{mSv}$, and it's maximum value did not exceed $50 \mathrm{mSv}$. The age of the exposed patients varied from 0 to 99 years, while the proportion of child CT was $6.5 \%$. Vital status has been estimated for $47.8 \%$ of the patients to the end of 2017 .

The completeness of the information collected in the database may be affected by cases of distant examinations of patients outside the Chelyabinsk region. However, it was assumed that such cases were rare. The lack of a unified national database for registering CT exposure of patients could lead to an underestimation of radiation burden of population.

Conclusion. The pooled database provides a unique source of information about an additional non-occupational ionizing radiation exposure. The data can be used to analyze the risk of exposure to low doses of diagnostic exposure among nuclear personnel and the population, and for the purposes of radiation-hygienic rationing as well.

Keywords: computed tomography, CT, MDCT, Registry, Register, Database, Population, Radiation risk, Risk analyzes.

Corresponding author: Osipov M.V., e-mail: ferrum76@mail.ru

For citation: Fomin E.P., Osipov M.V. Pooled database of Ozyorsk population exposed to computed tomography. REJR 2019; 9 (2):234-239. DOI:10.21569/2222-7415-2019-9-2-234239.

Received: $\quad 14.02 .19 \quad$ Accepted: $\quad 15.04 .19$

\section{ОБЪЕАИНЁННАЯ БАЗА ААННЫХ КОМПЬЮТЕРНО-ТОМОГРАФИЧЕСКИХ ОБСАЕАОВАНИЙ НАСЕАЕНИЯ Г. ОЗЁРСК}

\author{
Фомин Е.П. ${ }^{1}$, Осипов М.В.2
}

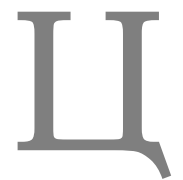

ель исследования. Создание расширенной базы данных миц, обследованных при помощи компьютерной томографии (КT), дАя оценки риска возможных отдалённых последствий воздействия малых доз ионизирующего излучения диагностического характера.

Материалы и методы. Исследование проведено ретроспективно. Архивные протоколы обследований жителей Озёрского городского округа, собранные за период с момента появцения компьютерной томографии в медицинских учреждениях города Озёрск и Челябинской области, оцифрованные, верифицированные и объединённые в эмектронную базу данных.

1 - ФГБУЗ КАиническая больница №71 ФМБА РФ. 2 - ФГУП ЮжноУральский институт биофизики ФМБА РФ. г. Озёрск, Россия. 


\section{RUSSIAN ELECTRONIC JOURNAL OF RADIOLOGY}

Результаты. В ретроспективном исследовании собрана информация о 22705 обследованиях жителей г. Озёрск, проходивших компьютерную томографию за период с 1993 по 2017 гг. Количество обследованных пациентов составило 14894, при этом $70,1 \%$ пациентов в течение всего периода наблюдения обследовались однократно. Максимальное количество повторных обследований одного пациента составило 19. Наибольшая доля КТ $(61,5 \%)$ представлена обследованиями головного мозга. Средняя величина эффективной дозы за обследование составима 3,2 мЗв, а максимальное значение не превышало 50 мЗв. Возраст обследованных варьировал от 0 до 99 еет, при этом домя обследованных в детском возрасте составила 6,5\%. Жизненный статус установлен дия 47,8\% обследованных.

Обсуждение. На полноту сбора информации в базе данных могут влиять исследования, проведённые пациентам исследуемой группы за пределами Челябинской области, однако предполагалось, что такие случаи являлись немногочисленными. Отсутствие единой национальной базы данных дмя регистрации обследований может приводить к недооценке кучевой нагрузки, получаемой пациентом в течение жизни.

Заключение. Объединённая база данных предоставляет уникальный источник информации о дополнительном радиационном факторе непроизводственного характера. Накопленные данные могут быть использованы дмя анализа риска воздействия мамых доз диагностического облучения у персонала радиационно-опасных объектов и населения, а также в целях радиационно-гигиенического нормирования.

КАючевые слова: компьютерная томография, КТ, МСКТ, база данных, радиационный риск, анализ риска.

Контактный автор: Осипов М.В., e-mail: ferrum76@mail.ru

Для иитирования: Фомин Е.П., Осипов М.В. Объединенная база даннъх компьютерно-толографических обследований населения г. Озёрск. REJR 2019; 9 (2):234-239. DOI:10.21569/2222-7415-2019-9-2-234-239.
Статья получена:
14.02.19
Статья принята:
15.04.19

\section{I}

\section{ntroduction.}

The question on long-term effects of low doses of ionizing radiation (IR) during X-ray examinations using computed tomography (CT) remains a subject of scientific debate and requires epidemiological studies with a long period of follow-up. International scientific experience in this field provides the necessity of creation of population registers which allows monitoring the health status and assessing the possible risk of long-term health effects [1-5]. However, at the moment, the authors have not found any publications concerning the creation of population registers of persons underwent CT in Russian Federation. In the present study, a pooled data on patients examined by computed tomography in medical units of Ozyorsk and Chelyabinsk region has been collected for the period of more than twenty years. The study is a continuation of the research studies [6-8] with an extended follow-up period and updated information about the sources of exposure.

\section{Material and Methods.}

The archival protocols of CT examinations of Ozyorsk residents from medical units of Ozyorsk and Chelyabinsk region during the period from
1993 to 2017 has been collected, digitized and verified. The follow-up period covers the time since the start of using the CT in medical units of the Chelyabinsk region. The criteria for inclusion in the study was the residence in Ozyorsk and nearby settlements (Tatysh, Novogorny and Metlino) and getting the $\mathrm{CT}$ examination in medical units of the Chelyabinsk region in the period from 1993 to 2017. Information on examination date, the patient's age at the time of the examination, the number of CT performed in various medical units, the type of scanner used, the anatomical area of study, the CT conclusion, and the effective dose and contrast enhancement data has been collected. Depending on the year and the equipment of the medical unit, both first-generation scanners (single-slice scanners) and multi-detector (spiral) scanners were used (see Appendix 1). The effective dose was calculated according to methodological guidelines [9]. Information about the vital status of patients was obtained from medical records and from Database for those who underwent second CT examinations. The person-time has been calculated using the date of 1 st $\mathrm{CT}$ examination to the date of the last $\mathrm{CT}$ examination, either until the death with date and cause of death known, or 


\begin{tabular}{|c|c|c|c|c|c|c|}
\hline № & Type of scanner & MDCT & \multicolumn{2}{|l|}{ Period } & \multicolumn{2}{|c|}{ Observations } \\
\hline 1 & Philips Tomoscan CX/Q & - & \multicolumn{2}{|l|}{ 1993-2007 } & \multicolumn{2}{|l|}{930} \\
\hline 2 & General Electric CT Max 640 & - & \multicolumn{2}{|l|}{$2000-2011$} & \multicolumn{2}{|l|}{5343} \\
\hline 3 & Toshiba Aquillion 64 & + & \multicolumn{2}{|l|}{$2008-2017$} & \multicolumn{2}{|l|}{518} \\
\hline 4 & General Electric LightSpeed VCT & + & \multicolumn{2}{|l|}{$2008-2017$} & \multicolumn{2}{|l|}{184} \\
\hline 5 & Siemens Somatom Definition Edge & + & \multicolumn{2}{|l|}{ 2014-2017 } & \multicolumn{2}{|l|}{200} \\
\hline 6 & GE LightSpeed 16 Cardiac Advantage & + & \multicolumn{2}{|l|}{$2008-2017$} & \multicolumn{2}{|l|}{243} \\
\hline 7 & General Electric BrightSpeed Elite16 & + & \multicolumn{2}{|l|}{$2012-2017$} & \multicolumn{2}{|l|}{15123} \\
\hline 8 & General Electric BrightSpeed & + & \multicolumn{2}{|l|}{$2011-2018$} & \multicolumn{2}{|l|}{164} \\
\hline & Total & & \multicolumn{2}{|l|}{ 1993-2017 } & \multicolumn{2}{|l|}{22705} \\
\hline \multicolumn{7}{|c|}{$\begin{array}{l}\text { Table 1. Characteristics of the database by the medical unit and the period of information } \\
\text { collected. }\end{array}$} \\
\hline \multicolumn{2}{|c|}{ Source of CT exposure } & Year & Records & $\%$ & Patients & $\%$ \\
\hline \multicolumn{2}{|c|}{ Central medical sanitary unit \#71, Ozyorsk } & 2003-2017 & 20467 & 90.1 & 13555 & 91.0 \\
\hline \multicolumn{2}{|c|}{ Regional clinical hospital, Chelyabinsk } & $1993-2017$ & 1556 & 6.9 & 1072 & 7.2 \\
\hline \multicolumn{2}{|c|}{ Regional oncological dispensary, Chelyabinsk } & $2007-2017$ & 518 & 2.3 & 167 & 1.1 \\
\hline \multicolumn{2}{|c|}{ Central clinical hospital, Kyshtym } & 2011-2017 & 164 & 0.7 & 100 & 0.7 \\
\hline \multicolumn{2}{|c|}{ Total } & 1993-2017 & 22705 & 100.0 & 14894 & 100.0 \\
\hline
\end{tabular}

until the date of leaving the place of residence (migration) in case when vital status information was not accessible at the end of the follow-up period.

\section{Results.}

The information on total number of archive records by the medical unit, and the period for which the information was collected is presented in Table 1.

The start of data collection in each medical unit corresponded to the start of using the CT scanner in this unit. The main source of information on CT examinations of Ozyorsk residents was the archival documents of the rentgenological department of Central Medical Sanitary Unit No. 71 (at present Clinical Hospital No. 71), which consists over $90 \%$ of the total number of records in the Database. Other possible sources of diagnostic CT exposure of Ozyorsk residents were analyzed and information was collected in nearby medical units of Chelyabinsk region. The total amount of information from these sources is more than two thousand CT observations, which is less than $10 \%$ of the total number of records in the Database. The number of examined patients leaves $65.6 \%$ of the total number of examinations, while 10434 patients $(70.1 \%)$ were examined once during the follow-up period. In the remaining cases $(29.9 \%)$, patients underwent multiple CT examinations. On average, during the follow-up period for each re-examined patient there were 3.5 CT procedures, and the largest number of examinations per patient was 19 .
The effective dose for one CT examination varied widely from 0.1 to $45.5 \mathrm{mSv}$, depending on age, gender, anthropometric parameters of patient, type of study, type of scanner, area observed, number of scans and the use of intravenous injection of contrast enhancement, which was performed according to clinical indications in 4345 examinations (19.1\%). Table 2 shows the age-gender and dosimetric characteristics of the Database.

The total number of child CT at the end of follow-up was less than $7 \%$ of all patients examined, the average effective dose for one child CT was lower than for adults due to the use of lowdose child CT protocols [8]. At the same time, taking into account the reasonableness of the appointment of a computer tomographic examination, the maximum radiation exposure in pediatric patients in some cases could reach $10 \mathrm{mSv}$ or more.

The structure of CT examinations depending on the area of exposure is shown in diagram 1 (Fig. 1).

The largest part of CT examinations (61.5\%) was performed to diagnose various pathological conditions of the head. The remaining anatomical areas - the chest, abdomen, pelvis, and spine were examined in $11.1-13.2 \%$ of cases, which is more than 2500 examinations for each area.

Vital status and person-time.

The vital status of patients examined was estimated as of December 31, 2017 (Table 3).

Vital status information was available in 
Table 2. Age at first exposure to CT, gender and average effective dose.

\begin{tabular}{l|l|l|l|l} 
Gender & Patients & $\%$ & Mean age* & Mean ED, mSv \\
\hline All ages $(0-99$ y.o.) & 14894 & 100.0 & 53.9 & $3.2(0.1-45.5)$ \\
\hline Both gender & 7198 & 48.3 & 56.6 & $3.3(0.1-45.0)$ \\
\hline Male & 7696 & 51.7 & 56.7 & $3.1(0.1-45.5)$ \\
\hline Female & \multicolumn{5}{l}{} \\
\hline Child CT (under 18 y.o.) & 1174 & 7.9 & 9.6 & $2.0(0.2-13.6)$ \\
\hline Both gender & 648 & 55.1 & 9.4 & $2.0(0.3-13.6)$ \\
\hline Male & 526 & 44.9 & 9.9 & $2.0(0.2-9.9)$ \\
\hline Female & \multicolumn{5}{l}{} \\
\hline *at first exposure to CT, years
\end{tabular}

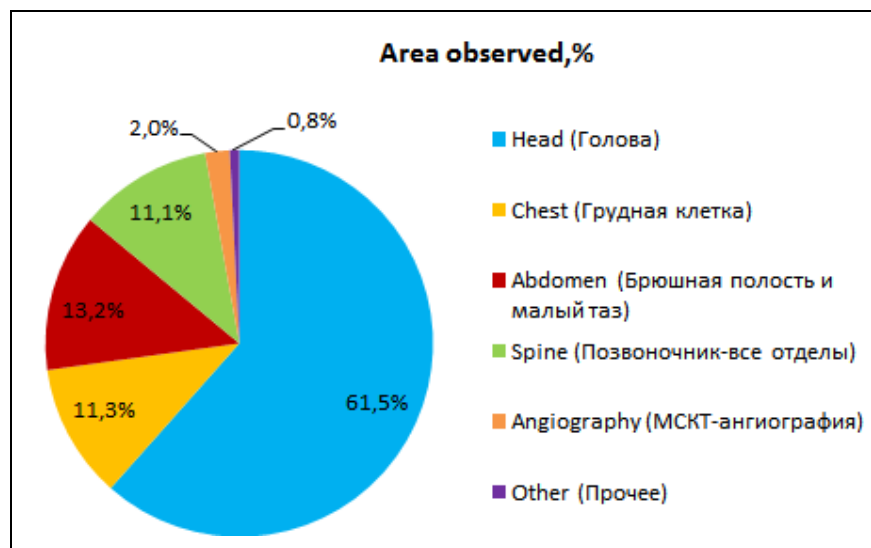

Fig. 1 (Puc. 1)

\section{Fig. 1. Diagram.}

The number of CT study by the area observed.

\section{Рис. 1. Аиаграмма.}

Количество исследований КТ по исследуемым областям.

$47.8 \%$ of the total number of patients. Of these, for $22.2 \%$ of persons at the end of follow-up the date and cause of death was known. The average age of death was 66 years (65 for male, 71 for female). More than $25 \%$ of patients, according to medical records, were alive at the end of follow-up. Average age at the end of follow-up for alive persons was 52.6 years. The average age at the end of follow-up for persons with unknown vital status information was 54.7 years.

The total number of person-years (pyr) and the proportion of deaths, depending on the age of patients, presented in table 4 .

The number of years of observation for each patient (person-time) varied from 0 to 26 years with the average 2.9 years. The total number of accumulated person-years of follow-up was 43891. At the same time, for those who died to the end of follow-up, this value reached 8025 .

Based on the average age of death in the study group, depending on gender, the predicted number of additional person-years was calculated for further prospective study. For patients who were alive at the end of follow-up, in case if the date of death for all of these persons will be known, the value of accumulated person-time will reach 60871 person-years. The predicted number of person-years of follow-up for persons with unknown life status, in case if the date of death for all of these persons will be known, will reach 141001 person-years. Thus, the total number of expected person-years for life-span study, in case of vital status is established for all patients, will be 209897 person-years.

\section{Discussion.}

To date, the availability of commercial medical services allows patients to undergo CT diagnostic examination in any accessible medical facility. In this regard, the study did not register possible CT examinations of Ozyorsk residents observed outside the Chelyabinsk region, but it was assumed that such cases were rare. An unified database of population for registering of medical diagnostic exposures discussed worldwide for more than ten years [10], could prevent an underestimation of the radiation exposure of the patient during computed tomography throughout life. One of the drawbacks of the study is the inability to verify the completeness of the collected archival data. In particular, this refers to the initial period of the study when no electronic information storage system in medical units has been used.

At present, there are many electronic databases of CT images available in medical units exists. However, they do not provide the possibility of follow-up. At the same time, the electronic archives of various medical units are often not interconnected themselves. The key feature of the Database described in present study is combining data from multiple sources of CT-exposure and provide the possibility for monitoring of the health status of patients.

Further epidemiological studies based on the data obtained should pay attention to the assessment of possible effects among central nervous system, since the largest proportion of CT ex 
Table 3. Vital status of patients by gender.

\begin{tabular}{|c|c|c|c|c|c|c|}
\hline Vital status & Both gender & $\%$ & Male & $\%$ & Female & $\%$ \\
\hline Alive & 3356 & 22,5 & 1650 & 22,9 & 1706 & 22,2 \\
\hline Dead & 3061 & 20,6 & 1772 & 24,6 & 1289 & 16,7 \\
\hline Unknown & 8477 & 56,9 & 3776 & 52,5 & 4701 & 61,1 \\
\hline Total & 14894 & 100 & 7198 & 48,3 & 7696 & 51,7 \\
\hline
\end{tabular}

Table 4. Person-years and proportion of deaths, depending on the age of the examined patients.

\begin{tabular}{|c|c|c|c|c|c|}
\hline Age group & Observed & Obs, \% & Pyr & Pyr,\% & Dead*, \% \\
\hline $0-17$ & 961 & 6,5 & 4396 & 10,0 & 2,5 \\
\hline $18-34$ & 1504 & 10,1 & 6495 & 14,8 & 7,8 \\
\hline $35-54$ & 4005 & 26,9 & 14680 & 33,4 & 16,5 \\
\hline $55-74$ & 6144 & 41,3 & 15260 & 34,8 & 26,3 \\
\hline $75+$ & 2280 & 15,3 & 3060 & 7,0 & 38,7 \\
\hline Total & 14894 & 100 & 43891 & 100 & 22,2 \\
\hline
\end{tabular}

aminations (more than 60\%) leads to the head exposure. Since IR is a risk factor for the malignant neoplasms development, it is necessary to conduct joint research using data from the national cancer registry[11], and also to take into account the possible modifying effect of the presence of a malignant neoplasm as a risk factor of second cancers [12] for patients undergoing CT examination for oncological pathology.

\section{Conclusion.}

The Database is a unique source of information on persons exposed to low dose of diagnostic exposure. The information accumulated in the Database allows conducting an epidemiological study using multifactorial analysis. Prospective study based on data from the Database is relevant in terms of assessing the lifetime risk of the long-term consequences of exposure to low doses of diagnostic exposure of a population. The expe-

\section{References:}

1. Mathews JD, Forsythe AV, Brady $Z$ et al. Cancer risk in 680 000 people exposed to computed tomography scans in childhood or adolescence: data linkage study of 11 million Australians. British Medical Journal. 2013; 346: f2360 doi: 10.1136/bmj.f2360

2. Bosch de Basea M, Espinosa A, Gil M, Figuerola J, Pardina M, Vilar J, et al. CT scan exposure in Spanish children and young adults by socioeconomic status: Cross-sectional analysis of cohort data. PLoS One. 2018; 13(5): e0196449.

3. Bosch de Basea $M$ et al. EPI-CT: design, challenges and epidemiological methods of an international study on cancer risk after paediatric and young adult CT J. Radiol. Prot. 2015; 35: 611-628.

4. Pearce MS, Salotti JA, McHugh K, Metcalf W, Kim KP, Craft $A W$, et al. $C T$ scans in young people in Northern England: trends and patterns 1993-2002. Pediatr Radiol. 2011; 41 (7): 832-8. rience of creating the Database can be used to create a national database of the population exposed to low doses of diagnostic exposure.

Acknowledgements.

The authors express their sincere gratitude to the teams of medical units and personally to Chief of the Chelyabinsk Regional Clinical Center of Oncology and Nuclear Medicine, Honored Doctor of the Russian Federation, Academician of the Russian Academy of Sciences, Ph.D., prof. Vazhenin Andrei Vladimirovich, Chief of the Chelyabinsk Regional Clinical Hospital, Honored Doctor of the Russian Federation, Ph.D, prof. Altman Dmitry Alexandrovich, and to director of the South Ural Institute of Biophysics, Ph.D. Romanov Sergey Anatolyevich, for their help and assistance.

Conflict of interests.

Authors declare no conflict of interest.

5. Pearce MS, Salotti JA, Little MP, McHugh K, Lee C, Kim KP, et al. Radiation exposure from $C T$ scans in childhood and subsequent risk of leukaemia and brain tumours: a retrospective cohort study. The Lancet. 2012; 380 (9840): 499-505.

6. Lebedev N.I., Osipov M.V., Babintseva N.A., Sinyak E.V., Fomin E.P. Checklist of patients undergoing $C T$ at the radiology department CMSU-71 of Ozyorsk. Russian Electronic Journal of Radiology. 2017; 7 (2): 110-116. DOI: 10.21569 / 2222-74152017-7-2-110-116 (in Russian).

7. Osipov M.V., Sokolnikov M.E, Fomin E.P. Prospects for using the medical dosimetric register of computed tomography to assess the contribution of medical diagnostic radiation to radiogenic risk. Issues of Radiation Safety. 2018; 89 (1): $67-73$ (in Russian).

8. Fomin E.P., Osipov M.V., Babintseva N.A., Sinyak E.V. Results of follow-up on patients examined using CT and MSCT in 


\section{RUSSIAN ELECTRONIC JOURNAL OF RADIOLOGY}

childhood and adolescencse. Russian Electronic Journal of Radiology. 2018; 8 (1): 137-144. DOI:10.21569/2222-7415-20188-1-137-144 (in Russian).

9. Radiation Safety Standards NRB-99/2009. SanPiN 2.6.1.2523 - 09 (in Russian).

10. Health risks from exposure to low levels of ionizing radiation (Committee to Assess Health Risks from Exposure to Low Levels of Ionizing Radiation, BEIR VII - Phase 2). National Research Council, National Academy Press, Washington D.C., 2006. 424 $p$.

11. National Cancer Register. Available at: http://nmicr.ru/onkopraktika/kantser-registr/ (Accessed 12/31/2018) (in Russian).

12. Osipov M.V., Sokolnikov M.E. Prior malignancy as a risk factor of the second cancer in a cohort of nuclear industry personnel. Russian Journal of Oncology. 2016; 16 (4): 190-194 (in Russian). 